\title{
A részmunkaidő karriert támogató szerepéről a magasan képzett nők körében
}

\author{
Oborni Katalin \\ https://doi.org/10.51624/SzocSzemle.2018.3.5 \\ Beérkezés: 2018.07.10. \\ Átdolgozott változat beérkezése: 2018.10.04. \\ Elfogadás: 2018.10.16.
}

\begin{abstract}
Összefoglaló: A részmunkaidő széles társadalmi támogatottságnak örvend Magyarországon. A közvélekedés és a foglalkoztatáspolitikai vélemények is mindenekelőtt a kisgyerekes nők munkaerőpiaci reintegrációjának és a munka-magánélet összeegyeztetésének az eszközeként tekintenek rá. Számos, főleg nemzetközi kutatási eredmény mutatott rá a részmunkaidős pozíciók feszültséggel teli, ambivalens helyzetére a munka-magánélet összeegyeztetés és karrierfejlődés vonatkozásában. Ez így van a magasan képzett nők esetében is, annak ellenére, hogy leginkább ők tudnak az igényeiknek, családi helyzetüknek és addigi munkatapasztalataiknak legmegfelelőbb részidős pozíciókban dolgozni. Ez a tanulmány középvezetői és szakértői pozíciókban dolgozó részidôs nők tapasztalatát és a részmunkaidőhöz való szervezeti hozzáállást vizsgálja meg, amihez egy etnográfiai szervezeti kutatás adatait használja fel. Az eredmények azt mutatják, hogy a vizsgált szervezetben formális és informális folyamatok is alakítják a részmunkaidős nők helyzetét, aminek következtében a részmunkaidő szervezeti narratívában megfogalmazott általános elérhetősége a gyakorlatban nem valósul meg. A részmunkaidő egy kisebb, jól körülhatárolható csoport számára volt elérhető. Újra megerősítést nyert az is, hogy a csökkentett munkaidő önmagában nem biztosít feszültségmentes munka-magánélet egyensúlyt. A megkérdezett nők mégis pozitívan álltak a részmunkaidőhöz, mivel a részmunkaidő illeszkedett elképzelésükbe a karrier/munka és család összeegyeztetéséről, és ezzel összefüggésben a részmunkaidő biztosította számukra, hogy a munkavégzés mellett is meg tudjanak felelni az intenzív szülőség egyfajta kiterjesztett, más családtagokat is bevonó elvárásának. Következésképpen, a részmunkaidő úgy vált legitim munkavégzési formává a szervezetben, hogy az nem bolygatta meg a szervezet elképzelését, gyakorlatait sem az ideális munkavállalóról, sem a hosszú munkaidő keretei között zajló munkavégzésről.
\end{abstract}

Kulcsszavak: részmunkaidő, nôi vezetők, karrier és család, intenzív szülőség

\section{BEVEZETÉS}

Az eddigi kutatások szerint a részmunkaidőnek számos negatív hatása van a magasan képzett nők karrierjére (Benschop et al. 2013; Hochschild 2001; Tomlinson-Durbin 2010). Továbbra is sok negatív sztereotípia él a részmunkaidőben dolgozó nőkről (Benschop et al. 2013; Dick 2010; Tomlinson-Durbin 2010), és a hosszú munkaidő elvárása is nehézségekkel és ellentmondásokkal teli helyzetet teremt a részmunkaidős nők számára (Hochschild 2001; Williams et al. 2013; Tomlinson-Durbin 2010). A szakirodalom arra is felhívja a figyelmet, hogy a részmunkaidő a társadalmi nemi szerepek hagyományos jellegű megerősödését is elősegíti (Christopher 2012; Webber-Williams 2008). 
Magyarországról kevés (és főleg kritikus hangvételü) olyan tanulmány áll rendelkezésre, amely a részmunkaidő karrierre gyakorolt hatását vagy a munka és magánélet összeegyeztetését vizsgálná a magasan képzett nők körében. A rendelkezésre álló szakirodalom a nemzetközi eredményekkel összhangban azt jelzi, hogy a magasan képzett középosztálybeli nőknek van a legnagyobb lehetőségük arra, hogy saját helyzetüknek és igényeiknek megfelelően tudjanak a részmunkaidővel élni (Geambaşu 2014; Kispéter 2012; Primecz et al. 2014). Ugyanakkor vannak olyan eredmények is, amelyek a részmunkaidőben dolgozó nőkkel kapcsolatos feszültségekre és negatív sztereotípiákra utalnak (Primecz et al. 2014; Tóth 2005). Ismert a részmunkaidő ellentmondásos hatása a munka-magánélet összeegyeztetésében (a többi posztszocialista országhoz hasonlóan, Formánková-Křížková 2015) és megmutatkoznak a negatív karrierkövetkezmények jelei is (Glass-Fodor 2011; Primecz et al. 2014). Továbbá nem ismeretlen a magyarországi kutatás számára sem a részmunkaidő „nőies jellegének” értelmezése, amely kiemeli, hogy a részmunkaidőnek megerősítő szerepe van az egyenlőtlen esélyek kialakulásában a munkaerőpiacon, a karrierfejlődésben, illetve a patriarchális társadalmi szerepek újratermelődésében (Geambaşu 2014; Gregor 2017).

Ez a tanulmány a részmunkaidő karrierben betöltött helyét és megvalósulásának lehetőségét vizsgálja a szervezet és az egyén szintjén is, a magasan képzett nők körében. A tanulmány megírásához egy nagyvállalatnál végzett etnográfiai kutatás szolgál alapul. Először azt nézi meg, hogy a vizsgált szervezetnek milyen a hozzáállása a részmunkaidőhöz. Majd a szervezeti képet a részmunkaidőről összehasonlítja azzal, hogy a részmunkaidőt igénybe vevő vezető vagy szakértői pozícióval rendelkező kisgyerekes nők milyen tapasztalattal rendelkeznek, hogyan vélekednek a saját részmunkaidejükről, milyen narratívába beágyazva értékelik azt. A kutatási téma abba a tágabb keretbe illeszkedik bele, amely a középvezetői szinten tanulmányozza a vezető nők karrieresélyeit. Az erre vonatkozó magyarországi kutatások szintén hiányosak, így ez a tanulmány a középvezető nők karrierhelyzetéről is újabb támpontokat nyújt.

A következő részben a tanulmány azokat az elméleteket mutatja be, amelyek a társadalmi nem bevonásával tárják fel a részmunkaidő helyét a munkahelyi szervezetben, majd értelmezi a részmunkaidős pozícióról való egyéni döntés szervezeti beágyazottságát. Ezután következik a magyar vonatkozású kutatási eredmények összefoglalása (kisebb kitekintéssel a nemzetközi eredményekre is) a részmunkaidőben dolgozó nőkről. A módszertan bemutatása után a tanulmány elemzi a szervezeti szereplők véleményét, elbeszélését a részmunkaidőről és részmunkaidős történeteket. Végül az eredmények összefoglalása értelmezi a részmunkaidőnek a szervezetben és az egyéni karriertörténetben betöltött szerepét.

\section{SZAKIRODALMI HÁTTÉR}


Az elméleti rész célja bemutatni a társadalmi nem szerepét a részmunkaidő szervezeti megközelítésében és a munkavégzéssel és karrierrel kapcsolatos szervezeti normák szerepét a magasan képzett nők részmunkaidő-választásában.

Az elméleti kiindulópont az, hogy a társadalmi nem alapvetően (de nem kizárólagosan) alakítja azt a szervezeti kontextust, amely meghatározza az egyén lehetőségeit a karrier építésében (Acker 1990; Nagy 2014). Így tehát a felszínen semlegesnek tűnő társadalmi nem múködésének az értelmezése - hogy az a szervezeti gyakorlatok, folyamatok mélyén egy sajátos szervezeti logika mentén hogyan konstruálódik (Acker 1990, 2006) - hozzájárul a részmunkaidős tapasztalatok és egyéni döntések szervezeti kontextusban való beágyazottságának értelmezéséhez (Benschop et al. 2013).

Acker (1990) értelmezésének a munkahelyi szervezetekről központi eleme, hogy az egyéneknek a társadalmi nemekhez kapcsolódó elvárásokon, normákon és sztereotípiákon keresztül eltérő helyzetük és lehetőségük van arra, hogy a szervezet által elvárt módon vegyenek részt a munkafolyamatokban, és hogy építsék karrierjüket (Acker 1990). A mai nagyvállalatok - igen jellemzően - alapvető elvárásként fogalmazzák meg, hogy munkavállalóik a munkaidejükön felül is minél többet áldozzanak fel magánidejükből (Geszler 2016; Williams et al. 2013), és lehetőleg rugalmasan álljanak - a szervezet igényei szerint - rendelkezésre (Hobson-Fahlén 2009).

Mindezek az elvárások továbbra is azt a szervezeti logikát követik, hogy az számít ideális és a karrierjét elkötelezetten építő munkavállalónak, aki állandó jelleggel elérhető, hosszú munkaórákat tud dolgozni, és a gondozói feladatok felelőssége alól alapvetően mentes (Acker 2006; Williams et al. 2012). Ezek az elvárások leginkább a teljes munkaidőben és a túlórát rugalmasan elvállalni tudó férfi vezetők számára megvalósíthatók a legkönnyebben (Acker 1990, 2006). De az ideális munkavállalók nemcsak folyamatosan elérhetők, hanem a munka prioritást élvez a magánéletbeli teendőik felett, feladatorientáltak, tudásuk legjavát adják, és törekszenek a magasabb szintű döntéshozói pozíciók elérésére (Benschop et al. 2013).

Az ideális munkavállalóra vonatkozó elvárás két ponton is kritikusan érinti a gyermeket nevelő, vezető beosztású nőket. Az egyik abból ered, hogy a munka-magánélet összeegyeztetése elsősorban a női munkavállalók problémájaként jelenik meg a szervezetben (Burnett et al. 2010; Hobson et al. 2011). A szervezet eleve feltételezi, hogy a női munkavállalók addig mentesek a gondozói feladatoktól, amíg gyermeket nem vállalnak (Acker 1990). Miután családot alapítanak, a szervezet úgy tekint rájuk, hogy ők lesznek azok, akik elvégzik a munka-magánélet összeegyeztetésével együtt járó feladatokat, tehát a munkahely a gyermekgondozói szerepüket is számon tartja innentől kezdve (Hobson-Fahlén 2009).

Az ilyen szervezeti hozzáállás közepette a férfi vezetők elkötelezettebbnek tưnnek a munkájuk, karrierjük iránt, mint azok a nők, akik részmunkaidőben dolgoznak, és ez az a másik pont, ami érinti a karrier alakulását. Az ambíció, az elköteleződés a munka iránt a szervezetek olvasatában szorosan összefügg azzal, hogy mennyi extra és önkéntesen felkínálható erőforrással rendelkezik a munkavállaló ahhoz, hogy a plusz, kihívással teli 
feladatokat elvégezze, és mellette folyamatosan fejlessze képességeit, tudását. Így lesz a sokat túlórázó (rendszerint férfi) munkavállaló nemcsak elkötelezett, hanem értékes is a szervezet számára (Benschop et al. 2013). Mindez azt eredményezi, hogy a szervezetek megközelítésében a munka és karrier iránti elkötelezettség összekapcsolódik a munkaidő hosszával és az állandó elérhetőséggel (Benschop et al. 2013; Lewis-Humbert 2010; Tomlinson-Durbin 2010; Williams et al. 2013). ${ }^{1}$

Ebben a szervezeti hozzáállásban a részmunkaidő a karrierambíciók ha nem is végleges, de legalábbis részleges vagy ideiglenes feladását jelenti (Benschop et al. 2013; Bleijenbergh et al. 2016; Dick 2010; Hochschild 2001; Tomlinson-Durbin 2010). Az ilyen hozzáállás a részmunkaidősökhöz szintén hozzájárul a negatív karrier következményekhez, és egy önmagát generáló folyamatba csap át például azzal, hogy kevesebb kihívással teli feladatot adnak a részmunkaidős vezetőknek, amivel azután kevésbé tudják bizonyítani szakmai rátermettségüket, ami végül kevesebb, visszafogottabb előrelépéshez vezet a karrierjüket illetően (Benschop et al. 2013; Dick 2010; Hochschild 2001; Sheridan 2004).

A nemzetközi szakirodalom azonban arra is felhívja a figyelmet, hogy ahogy a szervezeti folyamatok nehezítik a részmunkaidős nők karrierfejlődését, ugyanúgy segíteni is tudják (Bleijenbergh et al. 2016). Az eddigi eredmények alapján ebben nagy szerepe van a közvetlen vezetők támogatásának, mivel ők azok, akik jelentősen meghatározzák azt is, hogyan tekint egy szervezet egy-egy részmunkaidős munkavállalóra, hogy milyen típusú feladatokat kapnak, hogy kap-e valamilyen támogatást, például egy mentor személyében (Benschop et al. 2013; Dick 2010; Durbin-Tomlinson 2014). Mindemellett úgy tưnik, hogy a részmunkaidős női vezetők elfogadását a munka digitalizációja és az infokommunikációs technológiák térnyerése is segíti azzal, hogy a rugalmas rendelkezésre állás kiterjed időben, és áttevődik más, munkahelyen kívüli térbe is. Ez azonban azt is magával hozza, hogy a részmunkaidőben dolgozó vezetők sem mentesülnek a hosszú munkaóra, a rugalmasság elvárásai alól, ami által ők is szembesülnek a munka-magánélet összeegyeztetésének újfajta nehézségeivel (Benschop et al. 2013; Bleijenbergh et al. 2016; Hochschild 2001; Tomlinson-Durbin 2010).

A részmunkaidő tehát nem töri meg a karrierépítés maszkulin normáját és az erre épülő szervezeti logikát a szervezetek esélyegyenlőségi törekvései ellenére sem. Mindezek következtében a részmunkaidős pozícióban dolgozó magasan képzett nők „nem ideális” munkavállalóként jelennek meg a szervezetben (Benschop et al. 2013; Lewis-Humbert 2010; Tomlinson 2004; Williams et al. 2012). Ráadásul a részmunkaidő választása (mint ahogy a többi munka-magánéletet összeegyeztetni szándékozó eszköz igénybevétele is) egyéni felelősség és személyes döntés eredményeként jelenik meg a szervezetek hozzáállásában (Halrynjo-Lyng 2009; Hobson-Fahlén 2009).

1 A teljes képhez azonban hozzátartozik, hogy a hosszú munkaóra-kultúra a nagyvállalatokban nemcsak a nők, hanem a társadalmi szerepek fellazulásával egyre jobban a férfiak számára is jelentős feszültséget okozhat a harmonikus munkamagánélet kialakításában vagy a karrier építésében (Hochschild 2001; Holth et al. 2017; Kvande 2009; Williams et al. 2013). 
Mindeközben több szempontból is megdőlt az a tudományos megközelítés, hogy a nők karrierrel, munkával és ezzel összefüggésben a munka-magánélet összeegyeztetésével kapcsolatos döntéseit kizárólag az egyéni preferenciákból kiindulva meg lehetne magyarázni (Durst 2016; Nagy-Paksi 2015). A különböző szintű tényezők beazonosítása mellett (mint amilyenek a makroszintű társadalmi-gazdasági tényezők vagy a szervezeti szintű strukturális, kulturális tényezők (Halrynjo-Lyng 2009; Glass-Fodor 2011; Tomlinson 2004), a feltáró jellegú kutatások arra is figyelnek, hogy az egyén mennyire tudja a képességei (például jövedelem vagy a családtagok segítségnyújtásának mértéke) alapján igénybe venni, használni a rendelkezésére álló erőforrásokat (Hobson-Fahlén 2009).

Az erőforrások használatát (esetünkben a részmunkaidő igénybevétele) meghatározhatják azok a szervezeti folyamatok is, amelyek a munkavállalók felé eltérő elvárásokat támasztanak a társadalmi nemük alapján (Hobson-Fahlén 2009). De ugyanígy az egyéni preferenciákat és döntéseket az is alakítja, hogy milyen normákat tart helyesnek az egyén a társadalmi nemhez kapcsolódóan, amely attól is függ, hogy a döntést hozó egyénnek milyen a társadalmi helyzete (Durst 2016; Halrynjo-Lyng 2009). A középosztálybeli nők döntésében például a részmunkaidő mellett kiemelten fontosnak tűnik az, hogy a csökkentett munkaidő a gyermekkel együtt töltött minőségi időt biztosítja számukra (Geambaşu 2014; Halrynjo-Lyng 2009; Nagy-Paksi 2015).

Ezt az erős társadalmi-ideológiai elvárást, amely a középvezető nők identitását jelentősen meghatározza, az 'intenzív szülőség' kifejezéssel jelöli a szakirodalom (Kutrovátz 2017). Az intenzív szülőség normatív ideológiája azt a társadalmi szintű elvárást erősíti meg, mely szerint a családban a nők felelősek elsődlegesen a gyermekek gondozásért, következésképpen akkor tudnak jó anyák lenni, ha az intenzív szülőség elvárásai alapján gondoskodnak gyermekeikről, függetlenül attól, hogy milyen a munkaerőpiaci státuszuk és hogy milyen mértékű kihívást jelent számukra a munka és gyereknevelés összeegyeztetése (Christopher 2012). Érdemes ezért inkább intenzív anyaságról beszélni, mert az a társadalmi nyomás, ami ezzel jár, kifejezetten a nők felé fogalmazza meg az olyan elvárásokat, mint például, hogy legyenek a nevelés szakértői, költsenek sokat a gyermekük fejlesztésére, és legfőképpen, hogy töltsenek velük minőségi időt (Kutrovátz 2017). Az anyák vállát nagy felelősség nyomja, mivel ha nem így tesznek, azzal a szoros kötődés kialakulását, a gyermekeik egészséges fejlődését, és végső soron sikeres felnőtté válásukat kockáztatják (Christopher 2012; Green 2015). A részmunkaidő preferálása tehát a középosztálybeli, magasan képzett nők esetében összekapcsolható azzal is, hogy azért választják azt, mert kompatibilisnek érzik az intenzív anyaság gyakorlásával (Christopher 2012; Tomlinson-Durbin 2010).

\section{EDDIGI KUTATÁSI EREDMÉNYEK}

Magyarországon a részmunkaidőre - a rendszerváltozás utáni bevezetése óta - a kisgyerekes nők munkaerőpiaci reintegrációját (esélyegyenlőségi szempontból vezér- 
elve), illetve a munka és magánélet összeegyeztetését segítő eszközként tekintenek (Frey 2001; Geambaşu 2014; Gregor 2017). Mindettől nem függetlenül a társadalomban és a foglalkoztatáspolitikában is kitartó népszerúség övezi a részmunkaidôt: férfiak és nők egyaránt jó megoldásnak tartják a kisgyerekes nők gyerekszülés utáni munkába való visszatéréséhez és ezzel együtt a munka/karrier-család összeegyeztetésének segítéséhez (Frey 2001; Geambaşu 2014; Gregor 2017; Nagy 2003).

A magyar társadalomban a részmunkaidőnek ezt a jól kijelölt szerepét - tudniillik, hogy elsősorban a kisgyerekes nők számára fenntartott foglalkoztatási forma (amit egyébként a részmunkaidős foglalkoztatottakról fellelhető statisztikai adatok nem támasztanak alá, lásd. Gregor 2017) - erősíti az a társadalmi nemi szerepekhez való tradicionális hozzáállás is, amely szerint a gyermekek és a háztartás ellátása elsődlegesen a nők feladata és felelőssége (Frey 2001; Gregor 2016; Takács 2013). Az intenzív szülőségre vonatkozó elvárás aktualitását a magyar szülókre vonatkozó adatok is alátámasztják az apák esetében is (Kutrovátz 2017; Takács 2015).

Mindemellett, ahogy a többi posztszocialista országban is, az az elvárás is megfogalmazódik a kisgyerekes nők felé, hogy a gondozói szerep mellett a dolgozó nő szerepét is betöltsék (Kispéter 2012; Saxonberg-Sirovatka 2006; Takács 2013). A részmunkaidőnek a fenti szempontokat figyelembe véve kétféle haszna is van az erősen tradicionális nézeteket valló társadalom számára: egyrészt a csökkentett munkaidő lehetővé teszi a kettős szerep, a dolgozó anya szerepének betöltését. Másrészt a fennálló társadalmi nemi rendet sem bolygatja meg, miközben a nők munkaerőpiaci jelenlétét támogatja (Saxonberg-Sirovatka 2006; Takács 2013; Tóth 2005).

A széles társadalmi támogatottság ellenére a részmunkaidônek alacsony az aránya a foglalkoztatáson belül (kisebb eltérésekkel változott a bevezetése óta), ami nemzetközi összehasonlításban is alacsonynak számít (Gregor 2017; Nagy 2003; Takács 2013). 2016-os Eurostat- (2017) adatok például azt mutatják, hogy a teljes foglalkoztatáson belül 5\% körüli az aránya a részmunkaidônek; ${ }^{2}$ összehasonlítva: az EU28 tagország átlaga $32 \% .{ }^{3}$ Különösen azoknak a részmunkaidős állásoknak alacsony az aránya, amelyet a munkavállalók önkéntesen vállalnak el és nem jár együtt a jövedelmi helyzet vagy a karrier drasztikus romlásával. A részmunkaidő tehát sokkal inkább vágyott, mint elérhető foglalkoztatási forma, főleg a magasan képzett nők körében nagyobb az iránta való igény, mint a ténylegesen elérhető részmunkaidős állások száma (Geambaşu 2014; Gregor 2017).

Magyarországon kiemelkedő a nagyvállalatok szerepe a részmunkaidős pozíciók létrehozásában. A 2000-es évek első felében végzett kutatások eredményei még azt mutatták, hogy a vállalatok csak elvétve kínáltak részmunkaidőt a vezetô pozícióban dolgozó nőknek (Frey 2001; Nagy 2001; Tóth 2005), majd ahogy egyre jelentősebb lett az esélyegyenlőség kérdése, úgy nőtt a részmunkaidős lehetőségek száma is a nagyvállalatoknál

2 Ez az eredmény olyan adatokat tartalmaz, amelyeknél nem ismertetik külön-külön a kényszerủ és az önkéntes részidősök arányát.

3 Forrás: http://ec.europa.eu/eurostat/tgm/graph.do?tab=graph\&plugin=0\&pcode=tps00159\&language=en\&toolbox=sort. Letöltve: August 12th 2017. 
(Nagy 2003). Amikor Tóth (2005) a 2000-es évek elején vizsgálta meg egy multinacionális vállalatnál a vezetők munka-magánélet összeegyeztetési stratégiáit, mindössze néhány női vezetőt talált, akik részmunkaidőben tértek vissza a gyerekszülés után. A részmunkaidőnek így inkább a hiánya merült fel témaként. A megkérdezett női vezetők elvi síkon egyetértettek abban, hogy a részmunkaidő (vagy a távmunka lehetősége) hozzájárulna egy jobb munka-magánélet kialakításához, amit még azzal együtt is elfogadtak volna, ha alacsonyabb pozícióba tudtak volna csak visszatérni a gyerekszülés után. Az akkori pozíciójukkal azonban nem tartották összeegyeztethetőnek a csökkentett munkaidőt. Tóth szerint erősen tartotta magát az a kulturális koncepció a munkáról, hogy az a teljes és állandó idejú állást jelenti. Ezt alátámasztotta annak a kevés részmunkaidős nőnek a tapasztalata is, akik bár azzal elégedettek voltak, hogy részmunkaidőben dolgozhattak, de úgy érezték, hogy nem tartják őket a teljes munkaidőben dolgozókkal egyenrangú munkavállalónak (Tóth 2005).

A későbbi kutatások egyetértenek abban, hogy a magasan képzett női szakembereknek és vezetőknek van a leginkább lehetőségük arra, hogy olyan részmunkaidős pozícióban dolgozhassanak, amely megfelel az élethelyzetüknek, igényeiknek, azaz a részmunkaidőt a gyerekszülés után a gyerekgondozással összefüggő feladatok, a munka-magánélet összeegyeztetésének eszközeként (Kispéter 2012; Nagy 2003; Primecz et al. 2014), illetve a karrier megtartása érdekében veszik igénybe (Geambaşu 2014; Glass-Fodor 2011). Ez a helyzet azonban nem kizárólag a munkahelyi szervezetek esélyegyenlőséghez való pozitív hozzáállásán múlik, hanem sokkal inkább azon, hogy a részmunkaidőn keresztül tudják a vállalatok a magasan képzett, nagy munkatapasztalattal rendelkező női vezetőket, szakembereket megtartani és viszonylag korán visszacsábítani őket még a visszatérésre eltervezett idő előtt (Glass-Fodor 2011; Nagy 2003). Glass és Fodor (2011) pénzügyi vállalatok rekrutációs gyakorlatait vizsgálták, és többek között azt találták, hogy azokat a nőket, akik értékes munkaerőnek számítottak, jóval a gyed lejárta előtt visszacsábították a vállalataik. Néhányukat részmunkaidőben vették vissza. Jellemzően azok a nők tudták sikeresen teljesíteni ezt a második rekrutálást, akiknek korábban jó kapcsolatuk volt a vezetőikkel, és a gyed ideje alatt is kapcsolatban voltak egymással. A részmunkaidős pozíció kialakítása jellemzően már a gyermekekkel otthon töltött idő alatt (vagy akár előtte is) informálisan megkezdődött, és a nőkre nézve sokszor azzal a nyomással járt együtt, hogy a gyerekszülés előtti pozíciójukat (vagy egyáltalán a munkaviszonyukat) csak akkor tudták megtartani, ha az általuk eltervezettől eltérően korábban tértek vissza dolgozni. Ilyenkor ennek az egyezkedésnek az eredményeként valósultak meg a részmunkaidős pozíciók (Glass-Fodor 2011).

A közvetlen vezetők szerepének a jelentőségét a részmunkaidős pozíció kialakulásában Primecz és szerzőtársai is hangsúlyozzák (2014). Az ő kutatásuk munkavállalóbarát megoldásokat vizsgált meg 10 magyarországi nagyvállalatnál, és vizsgálatukban foglalkoztak a gyesről/gyedről visszatérő kisgyerekes anyákkal is. Minden szervezet, amelyet vizsgáltak, tudatosan foglalkozott a kisgyerekes nők reintegrációjával 
- ennek része volt, hogy felkínálták a részmunkaidő lehetőségét az anyák számára. Mindezek ellenére kevesen éltek a lehetőséggel. Kiemelik azt is, hogy a részmunkaidő biztosítása a kisgyerekes nők számára nem volt feszültségmentes a vállalatokban. A részmunkaidőt eleve a kisgyerekes nők felé irányuló pozitív diszkriminációnak tartotta a többi munkavállaló. Ezt támasztja alá az a tapasztalat is, hogy a részmunkaidős pozíciók létrejöttét elősegítette, ha a munkatársaknak nem kellett alkalmazkodniuk a részmunkaidős munkatárs csökkentett óraszámához vagy a megváltozott munkarutinjához, de az is megerősíthette bennük a pozitív diszkrimináció érzését, hogy a részmunkaidő az apák számára a gyakorlatban szinte elérhetetlen volt. Jellemzően tehát azok a nők tudták igénybe venni, akiknek jó kapcsolatuk volt a vezetőjükkel, és már elértek egy adott pozíciót abban a szervezetben, ahová visszamentek a gyerekvállalás után (Primecz et al. 2014). Ezek az eredmények megegyeznek a nemzetközi szakirodalom eredményeivel, amelyek szerint is azoknak a nőknek nagyobb az esélye egy számukra is megfelelő részmunkaidős pozíciót kialkudni, akik már a gyerekszülés előtt is ugyanazon a munkahelyen dolgoztak és a közvetlen vezetőjükkel jó kapcsolatot alakítottak ki, akivel aztán jellemzően informális csatornákon keresztül egyezkednek a részmunkaidős pozíció paramétereiről (Bleijenbergh et al. 2016; Hochschild 2001; Tomlinson 2004; Tomlinson-Durbin 2010).

A fellelhető kutatási eredményekből az is kiderül, ugyancsak hasonlóan a nemzetközi eredményekhez (Hochschild 2001; Tomlinson-Durbin 2010), hogy a részmunkaidő önmagában nem tudja biztosítani a munka-magánélet feszültségmentes összeegyeztetését (Tóth 2004; Primecz et al. 2014). Primecz és szerzőtársai (2014) nézték meg részletesebben, hogyan múködik a részmunkaidős pozíciókban a munkamagánélet összeegyeztetése. Több példát is hoztak, ami pozitívumként kapcsolható a részmunkaidőhöz (ilyen az intenzívebb munkavégzés, vagy annak az érzése, hogy személyes igényeiket figyelembe veszi a szervezet), de összességében arra jutottak, hogy a részmunkaidő önmagában nem eredményezett kiegyensúlyozott kapcsolatot a munka és a család között. Rendszeresnek tûnt például, hogy a kismamák esténként otthonról túlóráztak (Primecz et al. 2014).

Geambaşu (2014) tanulmánya világít rá annak jelentőségére, hogy a részmunkaidős nők nem egy homogén csoportot alkotnak: magyar és romániai nők részmunkaidős tapasztalatait hasonlította össze. Kialakított egy négy csoportból álló tipológiát, amivel értelmezni tudta, hogy a különböző részmunkaidős pozíciók más-más élethelyzethez, munkaerőpiaci helyzethez vagy karriertervekhez kapcsolódnak. A magasan képzett nőket két különböző, de egymást sokban átfedő csoportba sorolta be. Az egyikbe azok a nők tartoztak, akik számára a részmunkaidő az elsődleges gyerekgondozói szerep betöltését biztosította. A részmunkaidőnek számukra inkább szimbolikus, mintsem financiális jelentősége volt: a részmunkaidő biztosította azt a középosztálybeli életstílust, aminek központi eleme volt, hogy gyerekeikkel minőségi időt tudtak együtt tölteni. Tudtak volna tehát teljes állásban dolgozni, de jellemzően nem akartak. A másik csoportba azok a nők tartoztak, akik a karrierterveik bizto- 
sítása végett döntöttek a részmunkaidő mellett. A másik csoporttal ellentétben az idetartozó nők a teljes munkaidős állást választották volna abban az esetben, ha nem dolgozhattak volna részmunkaidőben, míg az előző csoportbeli nők inkább a gyerekgondozással összefüggő szabadság meghosszabbítását választották volna. Ennél a második csoportnál tehát a részmunkaidőnek inkább karriermegtartó szerepe volt, amellett, hogy az intenzív szülőség megélését is biztosította (Geambaşu 2014).

Összességében elmondható, hogy mára már elfogadott normává nőtte ki magát a részmunkaidő vállalati támogatása, amire leginkább a munka-magánélet összeegyeztetésének eszközeként tekintenek (Géring 2016; Hobson et al. 2013). Ugyanakkor továbbra is limitált az elérhető alternatív munkavégzési formák száma a vállalatoknál, és ha van, akkor azokat jellemzően a kisgyerekes nőknek tartják fenn (Glass-Fodor 2011; Hobson et al. 2013; Kispéter 2012; Primecz et al. 2014).

\section{MÓDSZERTAN}

A tanulmány megírásához egy közel négyezer munkavállalóval rendelkező pénzügyi nagyvállalatnál végzett etnográfiai kutatás szolgál alapul, amely a középvezetői karrier alakulását vizsgálja (a vállalathoz való bejutásról és a kutatás módszertanának kialakulásáról lásd bővebben Oborni [2017]). A vállalat egy külföldi tulajdonú pénzintézet leányvállalata Budapesti központtal és országos lefedettségű irodákkal. Az adatok nagy részét a budapesti központi irodában vettem fel. Pontos statisztikai adatokat nem volt lehetőségem gyüjteni, de az kiderült, hogy a vállalat középvezetői szintjéig a férfi és a női vezetők aránya megközelítőleg egyenlő. Az ott végzett megfigyelések alapján ez a vezetők horizontális eloszlását tekintve már nem volt igaz: sokkal több női vezető volt például a HR-osztályon, és mindössze egy az IT-fejlesztésekkel foglalkozó osztályon.

$\mathrm{Az}$ adatok gerincét a 2016 folyamán készült félig strukturált karrierinterjúk, illetve egy projektmunka résztvevői megfigyelése során gyüjtött adatok adják. ${ }^{4}$ A projektet a vállalat HR-osztálya indította el azzal a céllal, hogy felmérje a munkavállalók munka-magánélet összeegyeztetésével kapcsolatos elégedettségét és igényeit. A projektmunka egy résztvevői megfigyelés volt, aminek részeként 17 interjút vettem fel a munka-magánélet témájában. Ezeket az interjúkat a projektcsapattal közösen alakítottuk ki, de mindegyiket én vettem fel, majd írtam le, sőt az interjúkból készült tematikus összefoglalásomat is használta a projektcsapat a további munka során. Az itt közölt elemzéshez azokat az adatokat használtam fel a karrierinterjúkból és a projektmunka során készült interjúkból, amelyek a részmunkaidőre vonatkoztak. Mindkét interjúcsoportban középvezető és szakértői munkát végző nők meséltek a részmunkaidős tapasztalataikról, de azok az interjúrészletek is felhasználásra kerültek, ahol nem részmunkaidős interjúalanyok (férfiak és nők egyaránt) beszéltek a részmun-

4 A kutatás során használtam egyéb (nem résztvevői) megfigyeléses módszereket is az adatgyűjtéshez, mint például vállalati események megfigyelése vagy shadowing alkalmazása (a módszertanról lásd bővebben Oborni [2017]). 
kaidő lehetőségéről és arról, hogy milyen a részmunkaidős kollégákkal együtt dolgozni. Továbbá értékes adatforrásnak bizonyultak a HR-osztály projektmunkájának keretében tartott munkamegbeszélések is, ebből azokat a részeket használtam fel a feljegyzéseimből, amelyek a részmunkaidőről szóltak.

$\mathrm{Az}$ interjúalanyok közül tehát nem válogattam, így értelemszerűen azok a nők kerültek be a mintába, akik karrierútjuk során dolgoztak részmunkaidőben és egyébként interjút adtak a karrieralakulás vagy a munka-magánélet összeegyeztetésének témájában. A minta véletlenszerủ kialakulásához az is hozzájárult, hogy a részmunkaidős nők történetének vizsgálata mint téma azután vetődött fel, hogy egy korábbi elemzés eredménye már megmutatta, hogy a részmunkaidőben dolgozó nők csökkentett munkaidejük ellenére a munka-magánélet összeegyeztetésében nehézségekkel küzdenek (Oborni 2018). Ez az ellentmondás indított arra, hogy részletesebben nézzem meg a részmunkaidő alakulását a vizsgált vállalatnál (értve ezalatt azt is, hogy kinek és hogyan érhető el), és a karrierben betöltött szerepét.

Összesen 8 olyan részmunkaidős történet állt össze (közülük az egyik egy meg nem valósult részmunkaidőé), amelyeknek kisgyerekes nő volt a főszereplője (1. táblázat). A megszólalt nőknek 1 vagy 2 gyermekük volt, legtöbbjük házasságban vagy válás után új partnerkapcsolatban élt, ketten pedig egyedül nevelték gyerekeiket. Jellemzően a gyerekeik megszületése után tértek vissza a munkahelyükre részmunkaidőben (nemcsak a vizsgált vállalathoz), két kivételtől eltekintve rövidebb, átmeneti időre, ami után újra teljes munkaidős munkavállalók lettek. Az interjúalanyok közül hárman dolgoztak részmunkaidőben az interjúk készítése idején. Végzettségüket tekintve közgazdászok és HR-szakemberek voltak, két felső vezető nő kivételével középvezetői szinten dolgoztak, projekteket vezettek, szakértői munkát végeztek marketing/ PR és HR, ügyfélkezelési és folyamatszervezési területeken. A megszólalt részmunkaidősök csoportja abból a szempontból homogénnek tekinthető, hogy mindnyájan magasan képzett, középosztálybeli nők voltak. A legtöbbjük számára a részmunkaidő azt jelentette, hogy heti 30 órában foglalkoztatták őket. A ténylegesen ledolgozott órák száma azonban - hasonlóan a teljes munkaidős kollégáikéhoz - lényegesen több volt, amiben nagy szerepet játszott, hogy munkájuk és ők maguk is rugalmasan elérhetőek voltak az infokommunikációs technológiákon (IKT) keresztül (Oborni 2018). 
1. táblázat: A részmunkaidőben dolgozó nők föbb jellemzői

\begin{tabular}{|c|c|c|c|}
\hline 1. & $\begin{array}{c}\text { Felső középvezető } \\
\text { HR-osztály }\end{array}$ & $\begin{array}{l}\text { Házas, egy } \\
\text { gyermek }\end{array}$ & $\begin{array}{c}\text { Jelenleg is részmunkaidőben dolgozik: heti } 30 \\
\text { órában (3 munkanapra leosztva), határozatlan } \\
\text { ideig }\end{array}$ \\
\hline 2. & $\begin{array}{l}\text { Felső vezető } \\
\text { Marketingosztály }\end{array}$ & $\begin{array}{l}\text { Házas, egy } \\
\text { gyermek }\end{array}$ & $\begin{array}{l}\text { Korábban dolgozott részmunkaidőben a vizs- } \\
\text { gált vállalatnál, akkor is felső vezetőként, heti } \\
20 \text { órában, kb. fél éven keresztül }\end{array}$ \\
\hline 3. & $\begin{array}{c}\text { Középvezető } \\
\text { Marketingosztály }\end{array}$ & $\begin{array}{l}\text { Elvált, két gyer- } \\
\text { mek }\end{array}$ & $\begin{array}{l}\text { Jelenleg is részmunkaidőben dolgozik: heti } 32 \\
\text { órában (4 munkanapra leosztva), határozatlan } \\
\text { ideig }\end{array}$ \\
\hline 4. & HR-szakember 1 & $\begin{array}{l}\text { Házas, egy } \\
\text { gyermek }\end{array}$ & $\begin{array}{c}\text { Jelenleg is részmunkaidőben dolgozik: heti } 30 \\
\text { órában ( } 5 \text { munkanapra leosztva), nem derült } \\
\text { ki meddig marad részmunkaidőben }\end{array}$ \\
\hline 5. & HR-szakember 2 & $\begin{array}{l}\text { Házas, egy } \\
\text { gyermek }\end{array}$ & $\begin{array}{c}\text { Korábban dolgozott részmunkaidőben a } \\
\text { vizsgált vállalatnál, akkor egy alacsonyabb } \\
\text { státuszban, heti } 30 \text { órában (5 munkanapra } \\
\text { leosztva), kb. fél éven keresztül }\end{array}$ \\
\hline 6. & $\begin{array}{l}\text { Középvezető } \\
\text { HR-osztály }\end{array}$ & $\begin{array}{l}\text { Házas, két gyer- } \\
\text { mek }\end{array}$ & $\begin{array}{c}\text { Korábban dolgozott részmunkaidőben nem } \\
\text { a vizsgált vállalatnál, akkor is középvezető- } \\
\text { ként dolgozott, kisebb vállalatnál, heti } 30 \\
\text { órában (5 munkanapra leosztva), kb. fél éven } \\
\text { keresztül }\end{array}$ \\
\hline 7. & $\begin{array}{l}\text { Felső középveze- } \\
\text { tő, folyamatszer- } \\
\text { vezés és ügyfélke- } \\
\text { zelés területe }\end{array}$ & $\begin{array}{l}\text { Házas, két gyer- } \\
\text { mek }\end{array}$ & $\begin{array}{l}\text { Korábban dolgozott részmunkaidőben nem } \\
\text { a vizsgált vállalatnál, akkor felső vezető volt } \\
\text { egy jellemzően laposnak tartott szervezetben } \\
\text { a hierarchiát tekintve, heti } 20 \text { órában ( } 5 \text { mun- } \\
\text { kanapra leosztva) }\end{array}$ \\
\hline
\end{tabular}

$\mathrm{Az}$ adatok NVivo 11 szoftver segítségével lettek rendszerezve és elemezve. Három téma rajzolódott ki, ami alapján megragadhatóvá vált a részmunkaidő helye a szervezetben és a részmunkaidő egyéni szintű tapasztalata. Az elemzés először azt nézi meg, hogy (1) a nagyvállalati környezetben milyen tényezők járulnak hozzá egy részmunkaidős pozíció megvalósulásához (vagy meg nem valósulásához) a magasan képzett vezetői vagy szakértői munkát végző anyák esetében. Majd két olyan téma kifejtésével foglalkozik, amelyek azt mutatják meg, hogy mit jelent a vizsgált szervezetben részmunkaidősnek lenni: (2) hogyan tudnak a szervezet elvárásainak (hosszú munkaidő, rugalmasság) megfelelni a részmunkaidős anyák, és (3) hogyan magyarázzák választásukat a részmunkaidővel kapcsolatban.

\section{EREDMÉNYEK}

\section{A szervezeti és az egyéni narrativa ellentmondásai a részmunkaidó elérhetőségéröl}

A vállalat nagy hangsúlyt fektetett a karrierfejlesztésre. Jól kidolgozott rendszerük volt a vezetői utánpótlására és a munkavállalók folyamatos fejlesztésére. Kifejezetten támogatták a házon belüli utánpótlást és a horizontális irányú rotációt a különféle vezetői szinteken. Pénzügyi intézményről lévén szó, a teljesítmény kimutatása sok pozícióban számszerúsíthető volt. Ez segítette alátámasztani azt a szervezeti hozzáállást 
is, hogy nincs különbség a nők és a férfiak előrejutási lehetősége között, amit aztán az egyéni történetek és vélemények sokszor megcáfoltak. A meritokratikus elvek hangsúlyozása párosult egy nagyon erős belső versennyel, amiben a legjobban teljesítő munkavállalóknak közel 120\%-os eredményeik voltak. A karrierjük egy adott pontján külön figyelemben és támogatásban részesítette a nőket a vállalat: a gyerekszülés utáni visszatérést egy olyan programmal támogatták, aminek része volt a részmunkaidő.

A projektmunka során kiderült, hogy a munkavállalók alapvetően családbarátnak tartották a vállalatot, ${ }^{5}$ bár többen felismerték, hogy például a rugalmas munkavégzés inkább elvárás, mintsem lehetőség a munkavállalóra nézve. Sokan nehézségekről és feszültségekről is beszámoltak, leginkább a kisgyermeket nevelő nők (részletesebb elemzést lásd Oborni [2018]). Az interjúalanyok szinte kivétel nélkül megemlítették a részmunkaidőt, mint olyan munka-magánélet összeegyeztetését támogató eszközt, ami elérhető a vállalatnál. Érdekes volt, hogy a gyerekszülés előtt álló nók mennyire evidensnek tartották, hogy a gyerekszülés után részmunkaidőben fognak visszatérni. Többen is megemlítették az interjúk során, hogy ezt a megoldást választják majd, konkrét példákat is hoztak, hogy ki az, aki részmunkaidőben dolgozik, miközben vezető pozícióban van. De amikor azt kérdeztem tőlük, tudják-e, hogyan kell részmunkaidőt kérni, egyikük sem utalt egy formálisan múködő rendszerre, helyette a közvetlen vezetőjüket említették, akivel elsődlegesen egyeztetni fognak majd. Egy HR vezetőségi ülésen a felső vezetők is egyhangúlag leszavazták, hogy a részmunkaidővel foglalkozzanak, mondván, hogy az a vállalatnál már elérhető.

Ahhoz képest, hogy a részmunkaidő általánosan elérhető munka-magánélet összeegyeztetést segítő eszközként jelent meg a szervezeti narratívában, nem találkoztam sok részmunkaidőssel, és a részmunkaidős interjúalanyok is szerencsésnek és kivételesnek értékelték helyzetüket. Az egyik interjúalany, egy részidős marketingvezető, például nem is tudott másokról: „...én úgy tudom, én vagyok az egyetlen, aki részmunkaidôs, talán még van valaki, aki részmunkaidős, de más nincs a bankban, aki vezetöként részmunkaidős lenne...”. A többiek által hozott példák a részmunkaidős munkavállalókra egy idő után ismételték egymást, és egyértelmúvé vált az is, hogy a részmunkaidőben dolgozók személyes története - vagy azoké, akik szerettek volna részmunkaidőben dolgozni, de nem tudtak, vagy nem úgy, ahogyan az jó lett volna nekik - mást mutat a részmunkaidő elérhetőségére vonatkozóan.

Négy olyan, egymással is összefüggő tényezőt sikerült beazonosítani, amely előfeltétele volt a részmunkaidős pozíciók létrejöttének. Először is azokat a nőket szó-

5 A munka-magánélet összeegyeztetésére sok mindent ajánlott a vállalat. Volt például rugalmas munkaidő, részmunkaidő, távmunka, home-office rendszer, kötelezően kiveendő kéthetes szabadság. Néhány további példa a családbarát jellegre: a terepmunka során rendszeresen találkoztam a nyári időszakban gyerekekkel, akiket saját felelősségre, de be lehetett vinni egy-egy napra a munkahelyre, és volt egy szoba is, ahol a kisgyerekekkel együtt lehetett dolgozni. Ezt a kollégák jól tolerálták, akik ebbe a szobába mentek például megbeszélésre egy ott dolgozó anyával, de azért az is kiderült, hogy sok vezető nőnek ez mégsem volt segítség, hiszen a munkakörük jellege nem tette lehetővé, hogy amíg dolgoztak, a kisgyerekkel is együtt legyenek. Volt azután olyan autó, amit a nagyobb légtere miatt kifejezetten a 3 gyerekes (vezető beosztású) szülők igényelhettek. Ezenkívül egy óvoda megnyitását is akkor tervezték, amikor az adatfelvétel zajlott. Ezt sokan üdvözölték, ám feltünően azoknak tetszett a legjobban a kezdeményezés, akiknek nem volt még gyerekük vagy nem volt óvodáskorú gyerekük. A szervezet szociális alapon a gyerekek nyári táboroztatásához is hozzájárult. 
lították meg a részmunkaidővel a szervezet részéről, akiknek már volt munkakapcsolatuk a vállalattal a gyerekszülés előtt. Azok, akik újonnan kerültek a vállalathoz gyerekszülés után, nem kértek részmunkaidőt. Ehhez elég indoknak tűnt az, hogy nem volt korábban munkakapcsolatuk a vállalattal: „...ugye úgy jöttem, hogy kívülrôl jöttem, ezért kezdetben biztos, hogy nem kértem" (HR-középvezető, két kisgyerekkel). Azok a munkavállalók tehát, akik részmunkaidőt kaptak, a gyerekszülés előtt teljes munkaidőben dolgoztak már a vállalatnál.

$\mathrm{Az}$ is kiderült, hogy a részmunkaidős pozíciók megvalósulását egy hosszan tartó informális csatornákon való egyezkedés (második tényező) előzi meg. Hasonlóan ahhoz a folyamathoz, amit Glass és Fodor (2011) is leírtak, már a gyerekszülés előtt megkezdődött a részmunkaidős pozícióról való egyezkedés, ami a gyed időszaka alatt folytatódott. Ezeket a munkavállalókat így nem érte váratlanul, hogy részmunkaidőben tértek vissza dolgozni. Az egyezkedés során az is jellemző volt, hogy a vezetők kezdeményezték a részmunkaidő kezdetének idejét is. Az egyik részmunkaidőben dolgozó nő (marketingvezető, két kisgyerek) így emlékezett vissza erre:

„...eleve úgy mentem el, hogy ez a pozíció fent lesz nekem tartva, és egy ilyen egy-másfél éven belül visszajövök, csak közben itt is voltak mindenféle változások ... és akkor erre kért meg [a vezetö], hogy ez most akkor, tavaly májusban, hogy ez létre fog jönni így, és akkor jó lenne, ha vissza tudnék jönni”.

Azt látjuk tehát, hogy az interjúalany korábban tért vissza, mint ahogy tervezte, de maga az egyezkedés, a megkeresés nem érte váratlanul, mivel folyamatosan kapcsolatban maradtak. Egy másik interjúalany (HR-szakember 1, egy kisgyerek) történetéből az is világossá vált, hogy egy idő után el kellett fogadni az ajánlatot, bár ezt ő nem értékelte úgy, hogy a vezetője nyomást gyakorolt volna rá:

„Akkor volt másfél éves a kislányom, mikor visszajöttem. Mondjuk még maradhattam volna, de már akkor több ajánlattal megkerestek, amik nem voltak annyira testhez állóak, és akkor [a vezetöm] keresett meg azzal, hogy itt náluk, a csapatban van egy pozíció, és lehet 6 órában is, és mi sokat dolgoztunk együtt, tehát én a másik oldalról, jó néhány projektet láttam, amiben közös dolgunk volt."

Az is látszik ebből a két utóbbi idézetből, hogy a közvetlen vezetőnek (harmadik tényező) döntő szava van egy részmunkaidős pozíció létrejöttében. Ezzel az interjúalanyok is tisztában voltak:

„De ehhez [a részmunkaidőhöz] szerintem az kell, nem maga a terület adja, hanem nekünk egy olyan fönökünk van, aki ezt így nem csak hallja meg mondja, hanem csinálja is, tehát ez abszolút tôle függ, hogy az otthonról dolgozást, a részmunkaidôt, ezt az egészet igy alkalmazzuk." (Marketingvezető, két kisgyerek) 
Az a HR-középvezető (két kisgyerek), akinek nem sikerült részmunkaidős pozícióban csatlakoznia a vállalathoz, még explicitebb módon megfogalmazta a vezető szerepének jelentőségét:

„Tehát nálunk végül is minden ilyen intézkedés az a munkáltatói jogkörtől függ [a vezetőé], ... nincsen egységes szabályozási rend, tehát hogy a home office-t engedélyezi-e vagy a részmunkaidôt engedélyezi, tehát abszolút rá van bízva."

Bár ebből az idézetből úgy tűnik, mintha a vezető a lehetőségeihez mérten hozná meg a döntését (például hogy van-e olyan nyitott pozíció, amit részmunkaidőben lehet betölteni). De ezt maga az interjúalany cáfolta meg, amikor elmesélte azt a történetet, hogy ő maga sikeresen végigvitt egy olyan rekrutálási folyamatot, aminek a végén két kisgyerekes nő részmunkaidőben osztozott volna egy munkakörön, amit végül a leendő vezetőjük megvétózott a részmunkaidő iránti bizalmatlanságából kifolyólag. Ebből az esetből is az látszik, hogy a közvetlen vezető pozitív hozzáállása a részmunkaidőhöz feltétele annak, hogy egy pozíció realizálódjon. Nem véletlenül, a vezető szerepének jelentősége rendszerint abban a kontextusban jelent meg az interjúalanyok elbeszélésében, amelyben a vezető jóindulatáról, pozitív személyiségéről beszéltek. Általában ilyen elismerően nyilatkoztak a vezetőikről, mint ahogy az egyik részidős HR-szakember is: „[a vezető] ő abszolút érti ezt a helyzetet, és ő ebben partner, és én ezért hálás vagyok, egyébként nem tudom, hogy csinálnám" (HR-szakember 1).

Végül kiderült az is, hogy egy részmunkaidős pozíció a középvezetői szint felett (negyedik tényező) úgyszólván megvalósíthatatlan. Egy felső vezető nő (marketing), aki a második gyereke születése után szeretett volna részmunkaidőben visszatérni, úgy emlékezett vissza erre az időszakra: „...azt mondták, hogy meg se kérdezzem [a HRosztályon]”. Egy másik felső vezető nő (egy gyermek) ugyan tudott részmunkaidőben dolgozni - 6 hónap után tért vissza a munkahelyére ugyanabba a pozícióba, heti 20 órás részmunkaidőbe -, de mindössze 5 hónapig, és abba már nem ment bele a közvetlen vezetője, hogy átváltson heti 30 órás részmunkaidőbe, mondván, úgysem lenne különbség a napi 6 és 8 órás munkarend között. Ezt annak a felső-közép szintű HR-vezetőnek (egy gyermek) az esete is alátámasztotta, akinek sikerült megszilárdítania a heti 30 órás pozícióját, de azon az áron - ahogy az kiderült a vele készített interjúból és a közös projektmunka során -, hogy bármikor elérhető, sokat túlórázik, és a szabadnapjain is dolgozik. Ez a HR-es vezetőnő, másokkal együtt, azt is világosan megfogalmazta, hogy ő azért nem tervez a karrierjét tekintve magasabb szintre lépni, mert az már kizárná, hogy részmunkaidőben dolgozzon, vagy ahogy egy másik interjúalany (marketingszakember, két kisgyerek) fogalmazott a jövőre vonatkozó terveivel kapcsolatban: „Én szeretném megtartani ezt a munkarendet, ..., de kezdem elfogadni, hogy ez lehet, hogy a karrierem rovására fog menni." Az derült ki tehát, hogy a részmunkaidő a középvezetői szinten túl kivételként létezik. 


\section{Ambíció és rugalmasság: részleges adaptáció a hosszú munkaóra-kultúrához}

A nemzetközi szakirodalom beszámol arról, hogy a magasan képzett nőknek ugyan átalakulhat, de jellemzően nem csökken, vagy csak átmenetileg az elkötelezettségük a munka/karrier iránt. Ennek ellenére azzal szembesülnek, hogy karrierjük megreked, lelassul, miután részmunkaidőre váltanak (Benschop et al. 2013; Dick 2010; Tomlinson-Durbin 2010). Az itt vizsgált részmunkaidősök közül nem mindenki került vissza az eredeti pozíciójába vagy munkakörébe, de a szervezeti hierarchiában mind azonos szinten maradtak, még akkor is, ha a munkakörük megváltozott. Volt olyan (HR-szakember 2, egy kisgyerek), akinek ez nem tetszett, de még ő is pozitívan értékelte végül, mert „úgy az első időszakban nem kellett túlóráznom, ez úgy jó volt”, és végül csupán fél évig tartott a részmunkaidős időszak, és amikor újra teljes munkaidős lett, visszakapta azt a nagyobb szakmai kihívással együtt járó munkaterületet is, amivel a gyerekvállalás előtt foglalkozott. Az összes többi interjúalanyra igaz volt, hogy nem értékelték negatívan a részmunkaidős pozíciójukat, még akkor sem, ha nem tarthatták meg a korábbi munkakörüket, sőt inkább úgy közelítették meg az új területüket, hogy az kihívás, lehetőség a fejlődésre.

A megszólított részmunkaidősök tehát mind elégedettségüket fejezték ki, hogy csökkentett munkaidőben dolgoznak (erről bővebben a következő fejezetben), de természetesnek vették azt is, hogy ha idősebbek lesznek a gyerekeik, akkor újra teljes munkaidőben dolgoznak majd. A 8 óráról egyébként sem beszéltek úgy, mintha az kényszer lenne: „Egy idő után ez megoldható volt számomra, hogy tudjak 8 órás lenni” - mondta például a fent említett HR-szakember, amikor a teljes munkaidőbe való váltásról beszélt. Ugyanígy azt sem élték meg kényszernek, amikor eredeti terveiktől eltérően korábban tértek vissza dolgozni.

$\mathrm{Az}$ interjúkból az is kiderült, hogy karrierterveik inkább a szakmai tudás elmélyítésére vagy a szervezeten belüli horizontális mozgásra vonatkoztak. A részmunkaidőt pedig, egy-két kivételtől eltekintve (akik határozatlan időre megszilárdították részmunkaidejüket), átmeneti időszaknak tekintették. Azokról, akik már nem voltak részmunkaidősök az interjú ideje alatt, kiderült, hogy 1 évnél nem is voltak tovább részmunkaidősök.

A részmunkaidős időszak rövidsége és az a tény, hogy hajlandók voltak korábban visszatérni, mint ahogy azt eredetileg tervezték, talán még inkább azt mutatta, hogy elkötelezett munkavállalók, a csökkentett munkaidő ellenére is. Mindezt abban a kontextusban kell nézni, hogy nem terveztek a szervezeti hierarchiában a felső vezetői szintre lépni. Azt a szervezeti hozzáállást tehát ahhoz, hogy a részmunkaidő nem egyeztethető össze a magasabb vezetői szintekkel, nem bolygatták meg. Öszszességében tehát az a kép rajzolódott ki a részmunkaidőben dolgozó anyákról, hogy munkájuk iránt elkötelezettek maradtak a gyerekvállalás után is. Elismerték ugyan, hogy a családi kötelezettségeik miatt nem tehetik meg, hogy este sokáig dolgozzanak a munkahelyükön, amit sokszor hoztak fel példaként a részmunkaidős anyák akkor 
is, amikor arról beszéltek, hogy milyen gyerekkel együtt a munka-magánélet összeegyeztetése, de a munkát nem tartották kevésbé fontosnak az életükben.

Szervezeti szinten is pozitív kép élt a részmunkaidőben dolgozó nőkről. A vezetőik például nem láttak különbséget a részmunkaidős és a teljes munkaidős munkavállalók teljesítménye és elérhetősége között: „Semmi fennakadás nem volt” - mondta az egyik HR-es férfi vezető (akinek egyébként részmunkaidőben és sokszor otthonról dolgozik a felesége a vállalatnál) arról, hogy milyen volt, amikor korábban részmunkaidős dolgozott a csapatában, vagy egy másik alsó-közép vezetőnő, aki kifejtette, hogy a 6 és 8 órás munkanap között nincs különbség, amikor arra kérdeztem rá, hogy érezhető-e, ha részmunkaidős beosztottja van:

„Nem, 6 órásokkal semmiképpen nem, a szülők nagy része 6 órát vállalna. Egyáltalán nem érzékelhető, ... a 6 óra, ami a leginkább preferált lenne, az már nem érzékelhetô."

Ez a pozitív hozzáállás a részmunkaidősökhöz némileg ellentmond a szakirodalomnak a magasan képzett részmunkaidős nők negatív megítélésére vonatkozóan (Benschop et al. 2013; Dick 2010). Felmerülhet érvként, hogy azok, akik megszólaltak, nem akarták a szervezetet negatív színben feltüntetni. De ha megnézzük, hogy a részmunkaidősök hogyan dolgoztak, kiderül, hogy ők sem mentesültek a szervezet elvárásai, nevezetesen a hosszú munkaidő és a rugalmasan rendelkezésre állás alól, aminek következtében ők is elérhetőek voltak és sokat túlóráztak, hasonlóan a teljes munkaidőben dolgozó munkatársaikhoz (Oborni 2018), és amiről a nemzetközi szakirodalom már bőségesen beszámolt (Hochschild 2001; Tomlinson-Durbin 2010).

Az egyik HR-es felsővezető-nő (3 gyermek), akinek a csapatában dolgozott részmunkaidős, felvázolta, hogyan alakul ki a munkakapcsolat a részmunkaidősökkel, melynek lényege, hogy az elején vannak nehézségek, de amikor a részmunkaidős eljut odáig, hogy önállóan és egy kialakult munkarend szerint végzi a munkáját, már minden csak szervezés kérdése, például, hogy egy megbeszélést arra az időszakra szerveznek, amikor a részmunkaidős is a munkahelyen tartózkodik. Sokat segít az is, hogy a kollégák egy idő után megtanulják azt is, hogy ki mikor elérhető. Ezért volt hihető, amikor azt mondta az egyik részmunkaidős interjúalany, hogy olykor nem is derül ki, hogy valaki rész- vagy teljes munkaidőben dolgozik: „igen, rá szoktak csodálkozni a vezetők, hogy »te 6 órában vagy?" (HR-szakértő 1, egy kisgyermek).

Minden jel arra mutat tehát, hogy azt a munkát, amihez nem kell személyes jelenlét, otthonról is el tudják végezni, amivel élnek is a részmunkaidősök, és kiderült az is, hogy ez gyakori túlórához vezetett. A projektmegbeszéléseknek is állandó témáját képezte a túlóra, sőt az informális beszélgetések során is sokszor előkerült, hogy ki mennyit dolgozik, ki mikor megy haza: „...otthon szerintem ledolgozza a 8-10 órát is akár, hétvégén, éjjel...”; vagy „Mellettem ül a kolléganő, sohasem 6 órát, inkább 7 meg 8 órát dolgozik” - mondták a kollégáik a részmunkaidősökről. Ahogy kiderült, a legtipikusabb az volt, hogy a gyerekeik lefektetése után az éjszakai órákban újra elővették a munkát. Az egyikük (HR-szakember 2, egy kisgyermek) még azt is elmesélte, alig 
várta, hogy újra teljes munkaidóben dolgozhasson, mert akkor nem éjszaka kell befejeznie a napközben félbehagyott munkát. Ez azt is mutatja, hogy napi rendszerességú volt az éjszakai órákban végzett munka.

Számos más változatát említették az interjúalanyok annak, hogy milyen módokon túlóráztak. Előfordult, hogy egy kicsit később fejezték be a munkát a munkahelyen:

„Hát most az, hogy ráhúztam egy félórát, az megvan rendszeresen, de többet nem nagyon, mostanában nem nagyon. De ha ezt április-májusban kérdezed, az húzósabb lett volna." (HR-szakember 1, egy kisgyerek)

„És egyébként előfordul, tehát ez az 5 óra ez mostanában ilyen fél 6-ba átcsúszott, és van, hogy 6, fél 7-ig is itt vagyok, föleg amikor, most, hogy a nagyszülöknél vannak a gyerekek, és ilyenkor azért tovább is." (Marketing vezető, két kisgyerek)

A második idézet még azt is egyértelműen mutatja, hogy a túlórázás szinte észrevétlenül, de egyre jobban a részmunkaidő részévé válik. Kiderült az is, hogy dolgoztak a szabadnapjaikon és a betegszabadság alatt is. Egyikük felvázolta azt az informális és bejáratottnak tűnő rendszert, hogy amikor a gyerekei betegek, otthonról dolgozik, de nem veszik ki arra az időszakra a betegszabadságot, amit a beteg gyerekkel otthon töltenek, mert a rákövetkező héten ledolgozzák a hiányzó munkaórákat:

„És hát akkor én voltam vele otthon, de azt is így csúsztatással, meg szabadsággal meg tudtam oldani, nem kellett ilyen táppénzre mennem, viszont cserébe ugye a péntekjeim nem úgy néznek ki, hogy akkor nekem van egy egész péntekem, ezeket sokszor lecsúsztatom, és a sok csúsztatás után meg egy csomó olyasmi torlódik fel, ami elviszi a napomat, vagy az iskolában is valamiért csak fél nap tanitás van, szóval így igazából nem tudom úgy kihasználni”. (Marketingvezető, két kisgyerek)

Személyesen is meggyőződhettem arról, hogy akkor is elérhetők voltak, amikor egyébként nem volt munkaidejük: a projektmunka során nem okozott gondot, sőt teljesen természetesnek tünt, hogy felhívjanak egy részmunkaidős HR-vezetőt (felsőközép vezető, 1 gyermek) a szabadnapján egy félórás skype-os egyeztetésre, és mint kiderült, egyébként is dolgozott. Általános volt tehát, hogy ha nem dolgoztak (például munkaidő után), akkor is elérhetők voltak a kollégák, vezetők számára, mert például akadt egy sürgős munka:

„...azért nagyjából most már tudják, hogy egy napot nem vagyok, nem nagyon van sürgös, de ha van sürgős, akkor megtalálnak." (HR-szakember 1, egy kisgyerek)

Ezáltal mindig egyfajta készenléti állapotban voltak, amit jól bemutat ennek az interjúalanynak a beszámolója arról, hogy milyen az, amikor nem dolgozik:

„De nekem annyira része az életemnek a munka, és egyébként is gondolkodom rajta. Én ezt nem úgy élem meg, hogy na most akkor ez így a munka-magánélet rovására megy. És azért péntekenként pedig ugye, ha nem is dolgozok, vagy nem dolgozok, egy-két-három- 
szor rá szoktam nézni, de más az, amikor csakígy az ember a telefonján ránéz. Az, hogy az ember kinyitja a gépet, az havonta egyszer szokott elöfordulni, de akkor az hosszabb időre." (Marketingvezető, két kisgyerek)

Két dolog is látszik itt: az egyik, hogy az interjúalany elfogadja, természetesnek tartja, hogy elérhető, a másik pedig, hogy az elérhetőség az időbeliségére vonatkozik, mert egyébként az a „kiváltságuk” megmaradt, hogy a mindenki számára egyedileg kialakított munkarend szerint egy fix időpontban, ez jellemzően délután volt, ért véget a munkanap, de rögtön tegyük hozzá, hogy csak a munkahelyen.

Abban, hogy egy részmunkaidős bármikor elérhető legyen, nagy szerepe van az IKT eszközök használatának, amelyet egyébként a munka-magánélet összeegyeztetésében igen komplexnek, sőt ellentmondásosnak értékel a vonatkozó szakirodalom (Holth et al. 2017; Primecz et al. 2016), többek között azért - ahogy ez a fenti idézetből is látszik -, mert hozzájárul a munka-magánélet határainak elmosódásához és elősegíti a túlórát, mindezt a magánélet rovására, ugyanakkor lehetőséget biztosít a rugalmasságra is (Primecz et al. 2016). Így végül, ha fizikailag nem is, de on-line láthatók és elérhetők maradnak a részidőben dolgozó anyák. Következésképpen az előzőekben tett állítást, miszerint a munkavégzést befejezték a munkahelyen, arra szükséges módosítani, hogy felfüggesztették egy időre, amíg újra elérhetők nem lettek online, telefonon.

Összességében megállapítható, hogy a részmunkaidőben dolgozó anyák nem kérdőjelezték meg a hosszú munkaidő jogosultságát, elfogadták az erre vonatkozó szervezeti elvárást. Ugyanakkor a részmunkaidőben dolgozó nők állandó fáradtságról számoltak be, és arról, hogy a részmunkaidejük ellenére sem tudják megfelelően öszszeegyeztetni a munkát és a magánéletet. Leginkább a napi szintú túlóra volt az, ami megviselte őket, de az is kiderült, hogy azt is nehéz volt megoldaniuk, ha egy váratlan családi esemény miatt hosszabb időre kellett megszakítaniuk a munkavégzést.

A túlórából adódó helyzeteket különböző egyéni stratégiák bevetésével próbálták kezelni. Egyrészt hangsúlyos volt az egyéni készségek fejlesztése. Például, hogy megtanultak priorizálni, vagy nem hagyták, hogy feltorlódjon a munka, és egyfajta autonómiát éltek meg abban, hogy a saját munkavégzésüket szervezeték: a megbeszélésekre elérhetők voltak a munkaidejük alatt, a nagyobb koncentrációt vagy adminisztrációt igénylő munkát hazavitték. Másrészt, a gyerekneveléssel kapcsolatos napi teendőket sem egyedül végezték el. Volt, akinek állandó segítséget nyújtottak a nagyszülők (például egyiküknél úgy alakult, hogy a két nagyszülő felváltva vigyázott a gyerekre napközben, egy másik esetben a nagymama hordta haza a gyermeket az óvodából mindennap), de volt, aki állandó fizetett segítséget vett igénybe, legtöbbjük pedig a partnerével osztotta meg a gyerekgondozással együtt járó feladatokat, tipikusan a gyerekeknek a napközbeni intézményekbe való elvitelét, hazahozatalát.

Ezek az egyéni stratégiák mind azt mutatják, hogy a hosszú munkaidő „internalizálása” (Williams et al. 2013) a részmunkaidőben is megtörtént, amivel 
ha nem is teljes mértékben, de részben meg tudtak felelni az ideális munkavállalóval szemben támasztott követelményeknek, például, hogy legyenek rugalmasan elérhetők a munkahely számára, és helyezzék a munkát a családi kötelezettségeik elé.

\section{Az intenzív anyaság és az ideális munkavállaló ideológiájának összeegyeztetése}

Mindannak ellenére, hogy a részmunkaidős anyák sokat túlóráztak és a munkaidejükön kívül is elérhetők voltak, pozitívan értékelték azt a helyzetet, hogy részmunkaidőben dolgozhattak: „... alapvetően nekem ez az életforma tetszik” (marketingvezető, két kisgyerek), vagy ahogy az egyetlen felső vezető, aki részidőben dolgozhatott, mondta: „egy életminöség volt”.

A részmunkaidő által felszabadult többletidőt is nagyra értékelték: „...van idő arra, elintézzem azokat, amiket egy család mellett el kell, ... ez nekem nagyon sokat jelent" (marketingvezető, két kisgyerek). Az az idő tehát, amit nyernek, hozzájárul ahhoz, hogy preferálják a részmunkaidőt. A megnövekedett szabadidő azonban nem önmagában érdekes, hanem abban a kontextusban, hogy mit biztosít számukra az az idő, amit a részmunkaidővel nyernek. Ez az anyaság szerepének olyan módon való betöltése, amellyel azt tudták megélni, hogy annak ellenére is jó anyák tudnak maradni, hogy sokat dolgoznak. Az anyai szerepüket a kisgyerekeik mellett tehát megfelelően tudják betölteni, annak ellenére, hogy (sokat) dolgoznak.

Az a HR-vezető (két kisgyerek, korábbi munkahelyén részmunkaidős tapasztalat), akinek nem biztosították a részmunkaidőt, de szeretett volna így dolgozni, a hosszúra nyúlt munkaidőt egyértelmúen összekapcsolja azzal, hogy nem tud annyi időt és úgy a gyerekeivel lenni, ahogy az szerinte megfelelő lenne. Példának hozta fel, hogy nem tud elmenni értük az óvodába - ami egyébként megoldott volt, mert a másik szülő ment el a gyerekekért. „Ettől függetlenül nekem ez anyaként még nem jó érzés” - mondta, és folytatta azzal, hogy ráadásul már energiája sem maradt a családja számára, amikor a késő esti órákban hazaért. Elismerte ugyan azt is, hogy a részmunkaidő önmagában nem garancia arra, hogy a munkát és a magánéletet harmonikusan össze lehessen egyeztetni, de arra igen, hogy olyan munkabeosztása lehet, ami mellett akkor tud időt szakítani a gyerekeire, amikor az nekik is megfelelő. Az a felső vezető nő is, akinek hasonlóan volt összehasonlítási alapja, hogy milyen (4 órás) részmunkaidőben és teljes munkaidőben dolgozni, szintén azt emelte ki, hogy a részmunkaidő számára azt biztosította, hogy megfelelő időt tudott együtt tölteni a gyermekével, olyan minőségűt, amiben „jelen vagyok” - mondta. Szemben a jelenlegi munkaidejével, mert „vannak olyan napjaim, amikor azt gondolom, hogy csak túlélek."

A többi részmunkaidős hozzáállásából is az derült ki, hogy a gyerekgondozás többet jelent számukra annál, mint hogy ellássák a gyerekek körüli mindennapi teendőket. A megfelelően eltöltött idő és a gondoskodó odafigyelés volt a számukra fontos, mint ahogy például ez a HR-vezető (felső-közép vezető, egy kisgyerek) megfogalmazta: „... 
hogy legyen olyan napom, amikor anyja vagyok”. Az anyai szerep betöltésével kapcsolatban a válaszaik arra utalnak, hogy akkor tudnak ,jó anyák” lenni, ha minőségi időt tölthetnek együtt a gyerekeikkel. Ehhez nemcsak az kell, hogy legyen elég idő, amit együtt tudnak tölteni velük, de az is, hogy ők se legyenek túlságosan leterhelve a munkájukkal. Ennek van gyakorlati vonatkozása is, mert a részmunkaidő éppen azt a fajta munkabeosztást biztosította nekik, amit teljes munkaidősként nem láttak kivitelezhetőnek, azaz egy kialakított időbeosztás szerint mehettek el a munkahelyükről, vagy eleve úgy alakították, hogy bizonyos napokon nem dolgoztak (vagy otthonról dolgoztak). Amikor már kialakult a munka menetének rutinja, mindenki megtanulta, hogy mikor érhetők el a munkahelyen. Ez egyfajta kiváltság volt, mert azok, akik a gyerekeikért mentek az intézményekbe a délutáni időszakban, vagy azokon a napokon, amikor nem dolgoztak, biztosak lehettek benne, hogy odaérnek értük és együtt tölthetik velük azt a délutánt, estét. Azért is nevezhetjük kiváltságnak, mert ezzel ki tudtak kerülni egy az ideális munkavállalóval szemben támasztott elvárást, azaz, volt olyan szakasza a napnak, amikor igazoltan nem kellett elérhetőnek lenniük. De ahogy azt már fent láthattuk, ez inkább a munkahelyi láthatóságra, mintsem az elérhetőségre vonatkozott.

Egyértelmű volt számukra az is, hogy egy „jó anya”, még ha sokat dolgozik is, elérhető a gyermeke számára („állandó stressz, hogy odaérjek”), és nem fáradt, leterhelt abban az időben, amit a gyerekeikkel együtt tölt („amikor a gyerekkel vagyok, akkor 100\%-osan legyek"). Mindez értelmezhetó úgy, hogy az itt vizsgált, részmunkaidőben dolgozó nők törekednek megfelelni az intenzív anyaság elvárásainak (Green 2015). Ennek a társadalmi elvárásnak azonban nem volt könnyú megfelelniük, nagy volt a nyomás rajtuk, hogy mindig elérhetőek legyenek. Így annak ellenére, hogy csökkentett munkaidőben dolgoztak, ahogy azt már az előzőekben láthattuk, sok feladatot átadtak a nagyszülőknek, fizetett segítséget vettek igénybe, és partnereikkel is megosztották a gyerekneveléssel együtt járó feladatokat. Christopher (2012) értelmezése alapján megállapítható, hogy az intenzív anyaságot kiterjesztett módon gyakorolták: azonosultak azzal, hogy ők a fő gyerekgondozók, miközben a munkájuk iránt is elkötelezettek maradtak, így annak kivitelezéséhez, hogy a kettős terhet menedzselni tudják, számos feladatot delegáltak más szereplőknek. Következésképpen, a részmunkaidő végül is azt teszi lehetővé a magasan képzett nőknek, hogy egyrészt az ideális munkavállaló iránt támasztott elvárásoknak - részben - megfeleljenek, és másrészt feloldják az ideális munkavállalóval és az ideális anyasággal szemben támasztott elvárások közti feszültséget.

\section{KÖVETKEZTETÉSEK}

A tanulmány azt a kérdést vizsgálja, hogy a részmunkaidő milyen szerepet tölt be a nők karrierjében, amikor a gyerekvállalás után visszatérnek a munkahelyükre, és mi a helye a részmunkaidőnek egy olyan nagyvállalatban, mely alapvetően jellemezhető a hosszú munkaidő normalizálódásával és a teljesítményorientáltsággal. 
Az általam vizsgált vállalatra is igaz, hogy a részmunkaidőre alapvetően úgy tekintettek, mint ami elősegíti a kisgyerekes nők munkahelyi integrációját és karrierjük folytatását (Bleijenbergh et al. 2016; Dick 2010). Így a kisgyerekes nők eleve azzal az előfeltevéssel jelentek meg a szervezetben, hogy ők azok, akik elsődlegesen felelnek a gyerekgondozásért, ami a vonatkozó szakirodalom szerint megerősíti azt a kulturális koncepciót, miszerint a munka-magánélet összeegyeztetése elsősorban a női munkavállalók feladata (Burnett et al. 2010; Hobson et al. 2011).

A részmunkaidőről született eddigi szakirodalom eredményeihez hasonlóan az látszik azonban, hogy önmagukban a formális eszközök (esetünkben a kisgyerekes nők visszatérését segítő részmunkaidő vállalati programja) nem elégségesek ahhoz, hogy az alternatív munkavállalási formák általánosan realizálódjanak, azaz mindenki számára, pozíciótól, munkatapasztalattól függetlenül (Formánková-Křížková 2015; Glass-Fodor 2011; Primecz et al. 2014). A részmunkaidős pozíciók létrejötte komplex folyamat eredménye volt, amelyben a vezető vagy szakértő munkát végző anyák egyéni preferenciája nem az egyetlen meghatározó tényező (Hobson-Fahlén 2009). Ellenben a pozíció létrejöttét jelentősen elősegítette a már meglévő munkakapcsolat, egy hosszan tartó informális egyezkedési folyamat, a közvetlen vezetővel való jó kapcsolat, beleértve az ő pozitív hozzáállását is a részmunkaidőhöz, és hogy a részmunkaidős pozíció nem lépte át a középvezetői szintet. Következésképpen, azok a nők, akik részmunkaidőben dolgoztak, inkább kivételeknek számítottak, cáfolva azt a szervezeti narratívát, hogy a részmunkaidő általánosan létező lehetőség, bárki által igénybe vehető a szervezetben. Az itt bemutatott eset annak a példája, hogy ha a részmunkaidő elérhetőségét és feltételeit nem teszik vállalati szinten formalizálttá, akkor annak megvalósulása az egyéb informális tényezőktől függ.

A korábbi kutatási eredményekhez hasonlóan megállapítható, hogy a részmunkaidő segítheti a kisgyerekes nőket a munka és a gyereknevelés összeegyeztetésében (Primecz et al. 2014), de önmagában a munka és a magánélet harmonikus összeegyeztetését nem biztosítja, az idő szorítását nem könnyíti meg (Hoschchild 2001). A kapott eredményekből azt láthattuk, hogy a részmunkaidősök rendszeresen túlóráztak, és munkaidőn kívül is elérhetőek voltak a vezetőjük, kollégáik számára (amit a velük együtt dolgozó munkatársak is megerősítettek). Legtöbbjük további segítséget is igénybe vett a gyerekgondozáshoz.

A munka-magánélet összeegyeztetése során megélt nehézségek ellenére a részmunkaidősök alapvetően pozitívan értékelték, hogy részmunkaidőben dolgozhattak. Egyértelmúen kiderült, hogy a részmunkaidős anyák pozitív hozzáállása az intenzív szülői szerep betöltésének ideájával köthető össze. Ebben nagy szerepe volt annak, hogy a munkarendjüket úgy tudták kialakítani, hogy biztosak lehettek abban, délután, vagy azokon a napokon, amikor nem dolgoznak, meg tudják szakítani a munkavégzést arra az időszakra, amíg a gyerekeikkel lesznek a délutáni, esti órákban. Mindez azt is jelentette számukra, hogy egy viszonylag rövid, de a napnak egy számukra fontos szakaszával kapcsolatban azt élték meg, hogy kontrollt tudnak gyakorolni fe- 
lette. A beszámolóikból azonban úgy tűnt, hogy ezen az egyetlen „kiváltságon” kívül nem volt más, amivel kapcsolatban ilyen jellegú kontrollt éltek volna meg, ugyanis folyamatosan elérhetőnek kellett lenniük (időbeli elérhetőség). Mégis, a részmunkaidő így a magasan képzett nők számára lehetővé teszi, hogy megfeleljenek annak a társadalmilag erős elvárásnak, hogy - középosztálybeli, dolgozó/karrierjét építő nőként is - jó anyák legyenek: elérhetők a gyerekeik számára egy olyan időszakban, amelyet a gyereknevelés szempontjából fontosnak tartanak, hogy minőségi időt töltsenek el velük (Formánková-Křižková 2015; Geambaşu 2014). Így a részmunkaidő azt a helyzetet tudta megteremteni a magasan képzett nők számára, hogy a karrier és család közti választás helyett egyszerre felelhettek meg az intenzív anyaságra (Green 2015; Kutrovátz 2017) - de még inkább annak kiterjesztett formájára (Christopher 2012) - és a (posztszocialista örökségként itt maradt) dolgozó anyára vonatkozó társadalmi normáknak.

Összességében tehát a részmunkaidő a vállalati esélyegyenlőséget növelő szándék ellenére - egyetértve a szakirodalommal (Geambaşu 2014; Gregor 2017; Webber-Williams 2008) - többféle, a társadalmi nem által is meghatározott társadalmi szintű elvárást megerősít. Ilyen például, hogy elsődlegesen a kisgyerekes anyáknak kell elérhetőknek lenniük a gyerekeik számára, a kisgyerekes nők dolgoznak rugalmasan, vagy hogy a kisgyerekes nőknek nincsenek a felső vezetői karrierambícióik. A vállalati kultúra tehát addig engedélyezte a részmunkaidős pozíciókat, amíg azok nem bontották meg a társadalmi elvárásokra vonatkozó nemi rendet. Egy olyan HR-rendszer bevezetése, amely a részmunkaidőt nemtől (és esetleg a gyermekek meglététől) függetlenül, mintegy alanyi jogként tenné elérhetővé, valószínűsíthetően gyökeresen megváltoztatná a szervezeti kultúrát.

A fenti gondolatot alátámasztva, az IKT-eszközök intenzív használata segítette a részmunkaidősöket a túlóra és az állandó elérhetőség internalizálásában, sőt annak jelei is mutatkoztak, hogy nem minden munkával kapcsolatos feladatot tartottak munkavégzésnek, amit otthonról végeztek. Közvetve tehát az IKT használata ahhoz járult hozzá, hogy a részmunkaidő kompatibilis legyen a nagyvállalatok munkaidőre és a munka intenzitására vonatkozó elvárásaival. Mindez abba a folyamatba is beleillik, ami azt jelzi, hogy a digitalizációval a rugalmas munkavégzésre vonatkozó elvárásrendszer is átalakulóban van (Holth et al. 2017; Primecz et al. 2016; Williams et al. 2013). A vizsgált személyek esetében tehát a részmunkaidő azt biztosította, hogy nem kellett jelen lenniük (fizikailag) a munkahelyen, de helyette elérhetők tudtak lenni online. Továbbá, a nők részmunkaidős munkavégzése nem volt összeegyeztethető a felső vezetői pozíciókkal. A részmunkaidőben kivitelezhető rugalmasság, elérhetőség módja tehát csak a középvezetői szintig elképzelhető. Következésképpen, a részmunkaidő nem vesztette el a társadalmi nem által meghatározott voltát (azaz, hogy nőknek való munkavégzési forma), mivel az sem változott, hogy csak a középvezetői szinten, a gyermekgondozásból kifolyólag, hogyan kell rugalmasnak, elérhetőnek lenniük (Bleijenbergh et al. 2016). 
Nem véletlenül, a részmunkaidősökkel való elégedettségnek fontos részét képezte az, hogy állandó jelleggel elérhetők voltak a munkaidejükön kívül is. Abban a szervezeti kultúrában, ahol az ideális munkavállaló azzal is kinyilvánítja karrier iránti elkötelezettségét, hogy „hajlandó” a hosszúra nyúlt munkaidőt is bevállalni (Benschop et al. 2013; Bleijenbergh et al. 2016; Tomlinson-Durbin 2010), ott a részmunkaidősök karrierambícióit sem kérdőjelezik meg, amikor ők is hasonlóan a teljes munkaidőben dolgozókhoz, rugalmasan elérhetőek a munka számára. A tanulmány eredményei egyébként illeszkednek azoknak a szakirodalmaknak a megállapításaihoz, amelyek azt mutatják be, hogy a hosszú munkaidőt elváró szervezet meghatározza a vezetői karrier alakulását is - ebben a szervezeti logikában ugyanis a csökkentett munkaidő legitimizálja, hogy a részmunkaidős nők karrierlehetőségei lecsökkenjenek (Acker 2006; Dick 2010).

A vizsgált vállalatnál azonban a középvezetői szinten a részmunkaidősök karrier iránti lehetőségeit nem kérdőjelezték meg. Kevés jele volt annak is, hogy az interjúalanyok a karrier megrekedését élték volna meg. Ennek több oka is lehet: egyrészt a részmunkaidős foglalkoztatás általában nem tartott hosszú évekig. Ez a rövid idő megvédhette őket a karriert érintő negatív következményektől. Azok a nők pedig, akik állandó jelleggel meg tudták szilárdítani a részmunkaidős pozíciójukat, törekedtek arra, hogy ha nem is teljesen, de betöltsék az ideális munkavállaló profilját. A részmunkaidő adta keretek között is internalizálták a hosszú munkaidő elvárásának való megfelelést, és így, ha nem is teljesen, de jól meg tudtak felelni azoknak az elvárásoknak, amelyek az állandó elérhetőségre és a megszakítatlan munkavégzésre vonatkoztak. Láthattuk, hogy nemcsak a részmunkaidősök voltak elégedettek a pozíciójukkal, hanem a szervezet többi szereplője is elismerően nyilatkozott róluk. Mivel elérhetőek voltak és rugalmasan rendelkezésre álltak, nem alakult ki a részmunkaidős női vezetőkkel kapcsolatban az a negatív hozzáállás a karrierterveikre vagy a teljesítményükre vonatkozóan, amelynek alapja a karrierambíció összekapcsolása a hosszú munkaidővel (Benschop et al. 2013; Tomlinson-Durbin 2010). Alapvetően ambiciózus nőknek tűntek fel, akik egyébként is korábban mentek vissza dolgozni a gyerekszülés után, mint ahogy általában Magyarországon a nők.

Továbbá, nem terveztek a karrierjükben olyan változtatást, amely kizárta volna a részmunkaidőt. Így karrierterveik (középvezetői szinten maradás, horizontális célok, szakmai fejlődés) nem bolygatták meg azt a társadalmi nem által is meghatározott szervezeti rendet (gender regime), ami a felső vezetést jellemzően a férfiak számára látta megvalósíthatónak. Karrierszándékaik tehát illeszkedtek abba a szervezeti logikába, amely meghatározza, hogy egy részmunkaidősnek hol a helye a karriert tekintve a szervezeti hierarchiában. Egyetértve a korábbi szakirodalommal (Burnett et al. 2010; Glass-Fodor 2011), az eredmények alapján megkérdőjelezhető a részmunkaidő esélyegyenlőséget elősegítő szerepe a részmunkaidősökhöz való pozitív szervezeti hozzáállás ellenére is. Sokkal inkább az mutatkozik meg, hogy a részmunkaidő annak a módja, hogy a szervezet megtartsa a munkaerőpiaci szempontból értékes női munkavállalókat a gyerekvállalást követő időszakban. 
Összességében tehát a fenti következtetés azon tanulmányok sorába illeszkedik bele, amelyek szerint a nagyvállalatok továbbra is a társadalmi nem hierarchikus rendje által alapvetően meghatározott szervezetek maradtak, annak ellenére, hogy erőfeszítéseket tesznek az egyenlő esélyek biztosítására (Acker 2006, 2012; Burnett et al. 2010; Williams et al. 2012). Az itt bemutatott eset is azt mutatta meg, hogy formális (pl. a részmunkaidő nőknek való címzése) és informális folyamatok (pl. a személyes egyezkedés a közvetlen vezetővel) is alakítják azokat a szervezeti gyakorlatokat, amelyekben a nők elsősorban a gyermeküket nevelő munkavállalókként jelennek meg (Hobson-Fahlén 2009). Középvezetői szinten a részmunkaidő úgy vált legitimmé a kisgyerekes nők számára, hogy az nem bolygatta meg a szervezet elképzelését, gyakorlatait sem az ideális munkavállalóról, sem a hosszú munkaidő keretei között zajló munkavégzésről (Acker 2006; Tomlinson-Durbin 2010; Williams et al. 2012).

Az elemzés feltáró jellegű, ami nemcsak a kvalitatív módszer sajátosságaiból, hanem a minta kiválasztásának körülményeiből és a rekonstruált történetek csekély számából is következik. A minta homogenitása és az interjúk során rekonstruált történetek csekély száma kizárja a részmunkaidőre vonatkozó általános érvényű állítások levonását. Ez tekinthető a kutatás korlátjának is. Mindezek ellenére a kutatási eredmények érvényességét alátámasztja, hogy ebből a kisszámú történetből és formális/informális beszélgetésekből rekonstruált szervezeti hozzáállásból általános jellemzők, minták rajzolódnak ki a vizsgált célcsoportra vonatkozóan, illetve a korábbi kutatási eredmények által felvázolt tapasztalatokba is koherensen illeszkednek az itt feltárt tapasztalatok.

\footnotetext{
Abstract: There is considerable public support for women's part-time work in Hungary. It is commonly seen as an employment tool that helps women to re-enter the labour market after having children and also to reconcile work and life. It is already explored in the international literature that reduced working hours have negative consequences on career development and. Research on high-skilled, part-timer mothers in Hungary are limited, but it has been demonstrated that although these women are best placed to take appropriate part-time positions, they still experience difficulties with regards to their career development and work-life balance. This study presents the findings of an ethnographic study on high-skilled, parttimer mothers who work in managerial and professional roles, at a large company in the financial sector, in Hungary, and explores first the mothers' experiences of part-time work and secondly the organizational attitude to part-time work. It appears that both formal and informal organizational practices maintained women's part-time position including the access to such positions. It was found that the access to parttime positions is limited to a particular group of women. Similarly to previous findings in the literature, the mothers working part-time experienced difficulties in combining paid work and caring for children and frustration with their work-life balance. Despite all of the negative consequences in their work-life balance, the women who participated in this research were satisfied with having part-time positions. Working parttime was an integral part of their career story, and, more importantly, it provided them the opportunity to spend quality time with their children, which is defined as intensive parenting in literature. They owned all the responsibility for taking care of their children, however they delegated certain tasks to help them out with child care, therefore it is more precise to refer to their parenting practice as an extensive form of the intensive parenting. Furthermore, their part-time work did not challenge the organizational norm on career advancement. In summary, part-time work was applied in an integrative way in the researched work
} 
organization, but at the same time, it did not challenge the organizational attitude towards the 'long-hours working cultures' and the norm of the 'ideal worker'.

Keywords: part-time work, woman managers, career and family, intensive parenting

\section{Irodalom}

Acker, J. (1990): Hierarchies, jobs, bodies: A theory of gendered organizations. Gender and Society, 4(2): 139-158.

Acker, J. (2006): Inequality regimes. Gender, class, and race in organizations. Gender \& Society, 20(4): 441-464.

Benschop, Y. - Brink van den, M. - Doorewaard, H. - Leenders, J. (2013): Discourses of ambition, gender and part-time work. Human Relations, 66(5): 699-723.

Burnett, S. B. - Gatrell, C. J. - Cooper, C.L. - Sparrow, P. (2010): Well冈balanced families?: A gendered analysis of work冈life balance policies and work family practices. Gender in Management: An International Journal, 25(7): 534-549.

Christopher, K. (2012): Extensive mothering. Employed mothers' constructions of the good mother. Gender \& Society, 26(1): 73-96.

Dick, P. (2010): The transition to motherhood and part-time working: Mutuality and incongruence in the psychological contracts existing between managers and employees. Work, Employment and Society, 24(3): 508-525.

Durbin, S. - Tomlinson, J. (2014): Female part-time managers: Careers, mentors and role models. Gender, Work and Organization, 21(4): 308-320.

Durst J. - Fejős A. - Nyírő Zs. (2016): „Másoknak ez munka, nekem szívügyem.” Az etnicitás szerepe a diplomás roma nők munka-család konstrukcióinak alakulásában. socio.hu, 6(2): 198-225.

Frey, M. (2001): Nők es férfiak a munkaerőpiacon. In Nagy I. - Pongrácz T. - Tóth I. Gy. (szerk.): Szerepváltozasok, Budapest: TÁRKI, 9-29.

Geambaşu, R. (2014): Részidős: félmunkás? A női részmunkaidős foglalkoztatás főbb narratívái Magyarországon és Romániában. Erdélyi Társadalom, 12(1): 73-101.

Geszler, N. (2016): Behaviour-based work-family conflict among Hungarian manager father. intersections. East European Journal of Society and Politics, 2(3): 118-136.

Géring Zs. (2016): Hiányzó egyensúly a vállalati felelősségvállalás kommunikációjában - a munka és a magánélet egyensúlyának meg (nem) jelenése a vállalati honlapokon. Vezetéstudomány, 47(1): 2-17.

Glass, C. - Fodor, É. (2011): public maternalism goes to market: recruitment, promotion and hiring in Hungary. Gender \& Society, 25(1): 5-26.

Green, F. J. (2015): Re-conceptualising motherhood: Reaching back to move forward. Journal of Family Studies, 21(3): 196-207.

Gregor A. (2017): A részmunkaidős foglalkoztatás dilemmái. In Kovács M. (szerk.): Társadalmi nemek. Elméleti megközelítések és kutatási eredmények. Budapest: ELTE Eötvös Kiadó, 69-84. 
Gregor A. (2016): A nemi szerepekkel kapcsolatos attitűdök a 2000-es években Magyarországon [Attitudes on gender roles in the 2000s in Hungary], socio.hu, 89111.

Halrynjo, S. - Lyng, S. T. (2009): Preferences, constraints or schemas of devotion? Exploring Norwegian mothers' withdrawals from high-commitment careers. The British Journal of Sociology, 60(2): 321-343.

Hobson, B. - Fahlén, S. - Takács, J. (2011): Agency and capabilities to achieve a worklife balance: A comparison of Sweden and Hungary. Social Politics: International Studies in Gender, State \& Society, 18(2): 168-198.

Hobson, B. - Fahlén, S. (2009): Competing scenarios for European fathers: Applying Sen's capabilities and agency framework to work-family balance. The ANNALS of the American Academy of Political and Social Science, 214-233.

Hochschild, A. R. (2001): The Time Bind. When Work Becomes Home and Home Becomes Work. New York: Henry Holt and Company.

Holth, L. - Bergman, A. - MacKenzie, R. (2017): Gender, availability and dual emancipation in the Swedish ICT sector. Work, Employment and Society, 31(2): 230-247.

Jenkins, S. (2004): Restructuring flexibility: Case studies of part time female workers in six workplaces. Gender, Work and Organization, 11(3): 306-333.

Kispéter, E. (2012): Producing working mothers: Maternalist labor control in a Hungarian factory. PhD dissertation, Budapest: Central European University Department of Gender Studies.

Kvande, E. (2009). Work-life balance for fathers in globalized knowledge work. Some insights from the Norwegian context. Gender, Work and Organization, 16(1), 5872.

Kutrovátz, K. (2017): Parental time from the perspective of time pressure. The idea of intensive parenting. Review of Sociology, 27(4): 20-39.

Lewis, S. - Humbert, L. (2010): Discourse or reality?: “Work冈life balance”, flexible working policies and the gendered organization. Equality, Diversity and Inclusion: An International Journal, 29(3): 239-254.

Nagy B. (2001): Nôi menedzserek. Budapest: Aula.

Nagy, B. (2003): Hungarian companies' equal opportunity policies. Final research paper (Access: http://pdc.ceu.hu/archive/00001910/).

Nagy B. (2014). Háttérben. Kisérlet egy szervezeti nemi rend feltárására. Budapest: L'Harmattan Kiadó.

Nagy B. (2016): Ki áll a sikeres nő mögött? socio.hu, 6(2):117-141.

Nagy B. - Paksi V. (2015): A munka és a magánélet összehangolásának kérdései a magasan képzett nők körében. In Spéder Zsolt (szerk.): A család vonzásában. Tanulmányok Pongrácz Tiborné tiszteletére. Budapest: KSH NKI, 159-175. 
Oborni K. (2018): A családbarát munkahely - imázs vagy valóság? Esettanulmány egy nagyvállalat munka-magánélet összeegyeztetését támogató projektjéről. In Géring Zs. - Király G. - Nagy B. (szerk.): Dilemmák és stratégiák a család és munka összehangolásában. Budapest: L’Harmattan Kiadó, 276-303.

Oborni K. (2017): Az interperszonális kapcsolatok szerepe az etnográfiai szervezetei kutatásokban. Egy résztvevői szervezeti kutatás tapasztalatai. Vezetéstudomány, 48(4): 14-23.

Primecz H. - Kiss Cs. - Toarniczky A. - Szilas R. - Csillag S. - Bácsi K. - Milassin, A. (2014): Magyarországi „munkavállaló-barát” (employee friendly) szervezetek. Valóság vagy utópia (avagy mit tanulhatunk tőlük?). Vezetéstudomány, 45(10): 2-16.

Primecz, H. - Toarniczky, A. - Kiss, Cs. - Csillag, S. - Szilas, R. - Milassin, A. - Bácsi, K. (2016): Information and communications technology's impact on work-life interference: Cases of 'employee- friendly organizations'. East European Journal of Society and Politics, 2(3): 61-83.

Saxonberg, S. - Sirovatka, T. (2006): Failing family policy in post-communist Central Europe. Journal of Comparative Policy Analysis, 8(2): 185-202.

Sheridan, A. (2004): Chronic presenteeism: The multiple dimensions to men's absence form part-time work. Gender, Work and Organization, 11(2): 207-225.

Takács, J. (2013): Unattainable desires? Childbearing capabilities in early 21st century Hungary. In Oláh, L. Sz. - Fratczak, E. (eds.). Childbearing, Women's Employment and Work-Life Balance Policies in Contemporary Europe. Basingstoke - New York: Palgrave Macmillan, 179-206.

Takács J. (2017): Aktívan törődő apák Magyarországon. Szociológiai Szemle, 27(3): 104-126.

Tomlinson, J. (2004): Perceptions and negotiations of the "business case" for flexible careers and the integration of part-time work.Women in Management Review, 19(8): 413-420.

Tomlinson, J. - Durbin, S. (2010): Female part time managers: Work life balance, aspirations and career mobility. Equality, Diversity and Inclusion: An International Journal, 29(3): 255-270.

Tóth, H. (2005): Gendered dilemmas of the work-life balance in Hungary. Women in Management Review, 20(5): 361-375.

Webber, G. - Williams, C. (2008): Part-time work and the gender division of labor. Qualitative Sociology, 31: 15-36.

Williams, C. L. - Muller, C. - Kilanski, K. (2012): Gendered organizations in the new economy. Gender and Society, 26(4): 549-573.

Williams, J. C. - Blair-Loy, M. - Berdahl J. L. (2013): Cultural schemas, social class, and the flexibility stigma. Journal of Social Issues, 69(2): 209-234. 